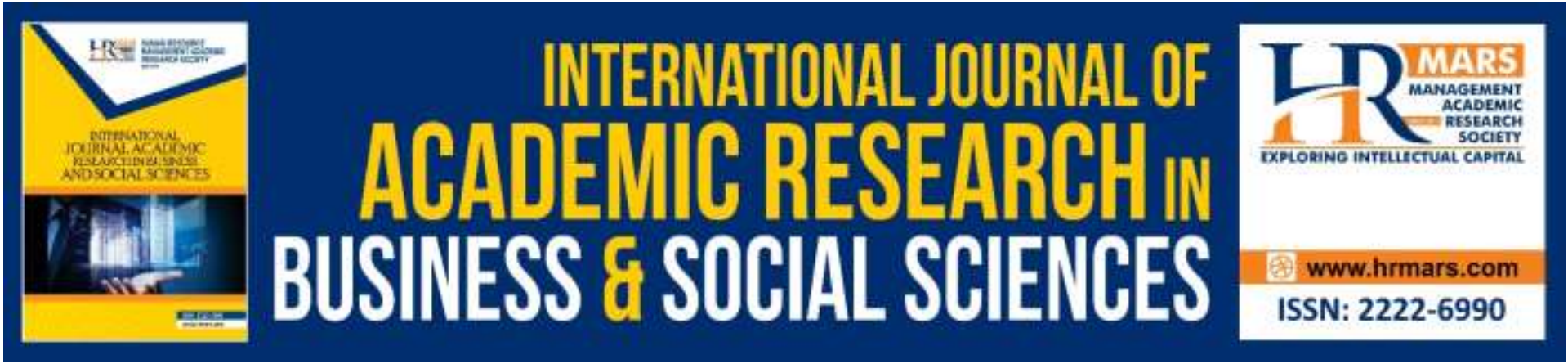

\title{
Effect of Diversity Management Strategies on Employee Retention among Staff of Nigeria Deposit Insurance Corporation
}

Nnadi, Chikezie Sunday Onoh, Umeh Anthony Chinedu

To Link this Article: http://dx.doi.org/10.6007/IJARBSS/v9-i7/6199

DOI: $10.6007 /$ IJARBSS/v9-i7/6199

Received: 24 May 2019, Revised: 10 June 2019, Accepted: 22 June 2019

Published Online: 26 July 2019

In-Text Citation: (Nnadi \& Chinedu, 2019)

To Cite this Article: Nnadi, C. S. O., \& Chinedu, U. A. (2019). Effect of Diversity Management Strategies on Employee Retention among Staff of Nigeria Deposit Insurance Corporation. International Journal of Academic Research in Business and Social Sciences, 9(7), 999-1019.

Copyright: (c) 2019 The Author(s)

Published by Human Resource Management Academic Research Society (www.hrmars.com)

This article is published under the Creative Commons Attribution (CC BY 4.0) license. Anyone may reproduce, distribute, translate and create derivative works of this article (for both commercial and non-commercial purposes), subject to full attribution to the original publication and authors. The full terms of this license may be seen

at: http://creativecommons.org/licences/by/4.0/legalcode

Vol. 9, No. 7, 2019, Pg. 999 - 1019

http://hrmars.com/index.php/pages/detail/IJARBSS

JOURNAL HOMEPAGE

Full Terms \& Conditions of access and use can be found at http://hrmars.com/index.php/pages/detail/publication-ethics 


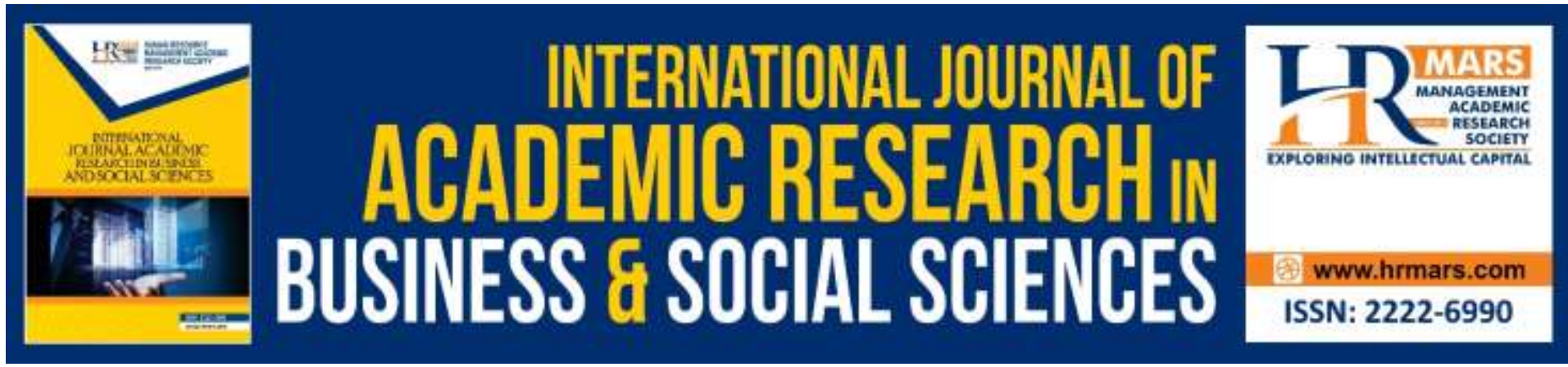

\title{
Effect of Diversity Management Strategies on Employee Retention among Staff of Nigeria Deposit Insurance Corporation
}

\author{
Nnadi, Chikezie Sunday Onoh (Ph.D.) \\ Business Administration Department, Faculty of Management Sciences, Enugu State \\ University of Science and Technology, Enugu, Nigeria. \\ Umeh Anthony Chinedu \\ Department of Economics, Enugu State University of Science and Technology \\ Email: umehchinedu47@gmail.com
}

\begin{abstract}
The study intended to ascertain effect of diversity management strategies on employee retention among staff of Nigeria Deposit Insurance Corporation. The specific objectives are to: examine the effect of communications in managing workforce diversity on employee retention among staff of Nigeria Deposit Insurance Corporation, ascertain the effect of performance management in managing workforce diversity on employee retention among staff of Nigeria Deposit Insurance Corporation, evaluate the effect of leadership initiative in managing workforce diversity on employee retention among staff of Nigeria Deposit Insurance Corporation and verify the effect of share responsibilities in managing workforce diversity on employee retention among staff of Nigeria Deposit Insurance Corporation. The area of study was south-East of Nigeria Deposit Insurance Corporation. Research design was sample survey research design. The population of this study comprises of the 120 staff of Nigeria Deposit Insurance Corporation. Information from questionnaires was analyzed using multi-norminal regression. The study conducted that performance Management, Leadership Initiative, Communication and Share Responsibility are effective diversity management strategies to promote employee retention in Nigeria Deposit Insurance Corporation. The selected workforce diversity strategies have positive and significant effect on employee retention. The management that holds onto diversity management strategies will go a long way to control workforce diversity in the area such as gender, ethnicity, religion, age, functional background, and organizational tenure and differences with respect to attitudes, personality, and values of employee. The following recommendations have been suggested by this study: Management of Nigeria Deposit Insurance Corporation should communication more and integrate employee on the need, mission, vision, of managerial decision and
\end{abstract}


policies; Management of Nigeria Deposit Insurance Corporation should adopt transformational leadership style to employee sense of belonging on the organization.

Keywords: Diversity Management Strategies, Employee Retention, Nigeria Deposit Insurance Corporation.

\section{Background to the Study}

Business globalization preference for teamwork to individual work and the changing workforce demographics have made workforce diversity management necessary for firms (Taylor, 2001). Firms acknowledged the importance of diversity in the workforce and started questioning the effectiveness of systems meant for a workforce that is not diverse (homogeneous workforce) (Human, 1996). The need to adopt human resource systems for labor force changes arose and many firms underwent changes in employment relationship.

Organizations were challenged to move away from doing employee headcounts to creating effective strategies for managing diversity (Taylor, 2001). The awareness of the importance of diversity is an essential aspect of organization performance and the effectiveness of firms operations, no matter how sophisticated they are, may not be sufficient to sustain growth unless there are strategies that complement the operations (Waiganjo, Mukulu, Kahiri, 2012). The effects of diversity on organizational behavior are complex and powerful (Aghazadeh, 2004).

There is no single best way to manage workforce diversity. In most cases, the approach used by a firm depends on the amount of pressure for diversity, the type of diversity in question, and managerial attitudes (Dass and Parker, 1999). Globalization is one such pressure and it presents challenges to managing the workforce. Some of the challenges as identified by Roberts, Kossek and Ozeki (1998) are deployment, knowledge and innovation dissemination, and talent identification and development. The main reasons for managing diversity as can be said is to improve productivity and remain competitive, to form better work relationships among employees, to enhance social responsibility, and to address legal concerns (Wentling and Palma-Rivas, 1998). During the past decade, the term "diversity" has been widely used to refer to the demographic composition of a team. In empirical studies, team diversity is usually measured using the compositional approach (Tsui \& Gutek, 2000), which focuses on the distribution of demographic attributes e.g. age, ethnicity and gender within teams. Research on inter-group relations shows that conflict is a common outcome when members of different groups come into contact with each other. By definition, diverse work teams include members who can be identified as belonging to distinct groups. When findings from research on inter-group relations is applied to understanding dynamics within diverse teams, the natural prediction is that diversity in work teams leads to negative outcomes such as disruptive conflict that must be avoided (Turner \& Haslam, 2001).

The method adopted for managing a diverse workforce can either be detrimental to the employee satisfaction and productivity or can bring out the full potential in them depending on how effective it is. Employees who feel more valued work hard while 
the group that consider themselves as minority group feel less valued leading to lower performance. This can be as a result of stereotyping, ethnocentrism and prejudice within a company (Goetz, 2001). Therefore, when an organization ignores the existence and importance of workforce diversity, conflicts can emerge and neither the corporation nor its employees will realize their potential.

The main undoing of diversity in the workplace is increase in conflicts. These conflicts arise largely due to ignorance, prejudice feelings or derogatory comments that cause lack of acceptance. These lead to negative dynamics such as ethnocentrism, stereotyping, cultural or gender clashes with the feeling of being superior to others. If management ignores such conflicts; the company performance may suffer (Otike, Messa and Mwalekwa, 2005).

Functional and social category diversity offers benefits for organizations (creativity, adaptation and innovation, and access to external networks) but there are costs that deter organizations from pursuing these benefits. The costs associated with organizational participation in diversity initiatives arise because managers and their employees perceive organizational conflicts and organize their interactions along social identity lines, so that temporal traps and collective fences surround diversity. Resolving the subordinate dilemmas of managerial and individual participation provides the key to resolving the dilemma of organizational participation. Social identity theory is used to understand the dilemmas and to develop possible resolutions, which should make the benefits of diversity management more immediately accessible to organizations and society.

Employees have been important resources to any organization. Based on their critical character, they can be termed the life-blood of an organization. Advancement in technology has caused most organizations to be more and more technology driven. However, this situation does not reduce the value of employees in an organization because technology requires human resources to operate. With issues such as globalization, competition is becoming keener and keener in most industries. This situation also affects the job market in the sense that organization demand in human resources to remain competition in their respective industries is higher. To remain more competitive, organizations need therefore not to only attract the best talents but also to retain them on the job for a long term. The toughest challenge that organizations encounter nowadays is not only how to manage the people but also how to keep them on the job as long as possible and how to maintain them vigorous and ambitious.

Effective employee retention is a systematic effort by employers to create and foster an environment that encourages current employees to remain employed by having policies and practices in place that address their diverse needs. A strong retention strategy becomes a powerful recruitment tool. Retention of key employees is critical to the long-term health and success of any organization. It is a known fact that retaining your best employees ensures customer satisfaction, increased product sales, satisfied colleagues and reporting staff, effective succession planning and deeply 
imbedded organizational knowledge and learning. Employee retention matters as organizational issues such as training time and investment; lost knowledge; insecure employees and a costly candidate search are involved.

Hence, failing to retain a key employee is a costly proposition for an organization. Various estimates suggest that losing a middle manager in most organizations' costs up to five times of his salary. Intelligent employers always realize the importance of retaining the best talent. Retaining talent has never been so important in the Indian scenario; however, things have changed in recent years. In prominent Indian metros at least, there is no dearth of opportunities for the best in the business, or even for the second or the third best. Retention of key employees and treating attrition troubles has never been so important to companies.

It is a fact that, retention of key employees is critical to the long-term health and success of any organization. The performance of employees is often linked directly to quality work, customer satisfaction, and increased product sales and even to the image of a company. Whereas the same is often indirectly linked to, satisfied colleagues and reporting staff, effective succession planning and deeply embedded organizational knowledge and learning.

Employee retention matters, as, organizational issues such as training time and investment, costly candidate search etc., are involved. Hence, failing to retain a key employee is a costly proposition for any organization. Various estimates suggest that losing a middle manager in most organizations, translates to a loss of up to five times his salary. Employee retention strategies help organizations provide effective employee communication to improve commitment and enhance workforce support for key corporate initiatives. This study focuses on the effect of diversity management strategies on employee retention among staff of Nigeria Deposit Insurance Corporation.

\section{Statement of Problem}

Workforce diversity management is gradually being adopted in many Nigerian organizations (Edeltraud and Ukur, 2011). Even though there are concerted efforts to invest in workforce diversity management to boost employee morale, employee retention and organization performance, organizations rarely achieve their expected benefits. This is because the promotion of workforce diversity is also very low among Nigerian institutions given that diversity initiatives have no basis in law in most of the organizations (Mary 2002).

The theory of social identity and realistic conflict theory (RCT) in the workforce explains that every being has a need of feeling that they belong to a particular group in the society and that most people act in self interest, workplace being no different (Tajfel, 1982; Sherif, 1966). This sense of belonging gives individual sense of being part of the organizational system both formal and informal settings. 
Conflicts that arise within a workforce due to self-interest are inevitable. If the conflicts can be managed and controlled, creativity and performance can be increased. Some of the challenges faced in workforce diversity management are political influence, cultural differences, omission of talented workforce due to bureaucracy in a company and majority companies comply with workforce diversity due to legal implications and not the general benefits it accords them thus limiting their involvement in diversity management (Shen, Chande, D'Netto and Monga, 2009).

In Nigeria, the issue of diversity management in workforce has been given attention lately with corporations being urged to comply with the regulations set to monitor the diversity. With this, the study therefore identifies innovative strategies for managing workforce diversity in Nigerian leading corporations in present global scenario. The promotion of workforce diversity have seen some organizations put in place policies that protect diversified groups (Rachele, 2010).

In a progressive and multi-racial/ethnic country like Nigeria which has opened up to globalization over the recent years, there needs to be more deliberate research efforts on approaches to manage workforce diversity if concerns over ethnicity and gender imbalance in the workplace are going to be contained before they explode and become human rights issues.

So far, quite a number of studies have been done in the field of workforce diversity management in Nigeria focusing on the challenges of managing diverse workforce (Edeltraud \& Ukur, 2011), effects of workplace diversity management on organizational effectiveness (Otike, Messah \& Mwalekwa, 2009) and some conduct their research with local perspective like the nonprofit sector in Nigeria (Kanyinga \& Mitullah, 2006). There is no research that has been done on the effect of diversity management strategies on employee retention among staff of Nigeria Deposit Insurance Corporation to manage their workforce diversity given the growth of businesses at the global level. This paper therefore seeks to bridge the gap by reviewing strategies adopted by Nigeria Deposit Insurance Corporation in respect with the global scenario.

\section{Objectives of the Study}

The main objective of this study is to investigate the effect of diversity management strategies on employee retention among staff of Nigeria Deposit Insurance Corporation. The specific objectives are to:

1. Examine the effect of communications in managing workforce diversity on employee retention among staff of Nigeria Deposit Insurance Corporation.

2. Ascertain the effect of performance management in managing workforce diversity on employee retention among staff of Nigeria Deposit Insurance Corporation.

3. Evaluate the effect of leadership initiative in managing workforce diversity on employee retention among staff of Nigeria Deposit Insurance Corporation. 
4. verify the effect of share responsibilities in managing workforce diversity on employee retention among staff of Nigeria Deposit Insurance Corporation.

\section{Conceptual Framework}

\section{Concept of Diversity Management}

Traditionally, the term diversity has been widely used to refer to the demographic composition of a workforce. Some studies have looked at diversity using the compositional approach, otherwise known as Surface-level diversity (SLD) or demographic diversity, which refers to the extent to which a unit is heterogeneous on characteristics such as gender, ethnicity, religion, age, functional background, and organizational tenure (Tsui and Gutek, 2000; Fajana, et. al, 2011). In addition to the surface-level composition of the group, deep-level diversity (DLD), otherwise seen as differences with respect to attitudes, personality, and values, has also been investigated (Barrick, et.al, 1998; Harrison, et. al, 2002; Thatcher, et. al. 2003).

Workforce Diversity Management is the ability of a manager to achieve success for an organization by making the best of use of the similarities and differences among employees in terms of age, cultural background, physical abilities and disabilities, race, ethnicity, religion, sex, as well as in terms of personality, values, attitudes, perception and cognitive style. Individuals who think towards deep level diversity are more likely to perceive themselves as similar, rather than dissimilar, to members of their workgroup on unobservable qualities (Liao, et. al, 2008).

To Daft (2008) Workforce diversity refers to a workforce made up of people with different human qualities or who belong to various cultural groups. The author regarded individual diversity to include people different from themselves along the dimensions such as social background. Workforce diversity as noted by Robbins and Judge (2011) acknowledges a workforce which comprised women and men. As the authors went on to observe, these individuals with variety of physical or psychological abilities. Diversity management is about finding ways to get the diverse contributions from employees.

It may seem that the dynamics of diversity are especially salient in teams. This may be because it has been observed that where the level of face-to-face interaction is high, members often rely on one another to perform their tasks effectively (Tsui and Gutek, 2000). Indeed, empirical research in organizational and laboratory settings suggests that diversity make a difference for group outcomes and significantly affect the experiences of the individuals within the team (Harrison et.al, 2002; Jackson, et.al, 2003).

Diversity Management is the strategic process to manage a diverse workforce including the fight against stereotypes, prejudice and all kinds of discrimination due to the individuals' perceptions and assumptions - in the manner to maximize the benefits and minimize the barriers of different opinions, behaviors and attitudes of human beings within a company. 
Diversity management refers to as planning and implementing organizational systems and practices to manage people so that the potential advantages of diversity are maximized while its potential disadvantages are minimized (Olsen, \& Martins, 2012).

According to Flood and Romm (1996), Diversity Management is about managing the increasing diversity of issues that confront humankind in contemporary organizational and society affairs. Preservation of diversity is assumed to enhance the opportunities people have to manage intelligently and responsibly the most existing issues that arise in organizational and social affairs. Therefore, by diversity at the workplace more choices are made available for people to manage organizational and social affairs.

\section{Workforce Diversity Management Strategies}

Communication: Communication is a process of passing information and understanding from one person to another. Communication is essentially the ability of one person to make contact with another and make himself or herself understood.

Performance Management: Performance management is the process of creating a work environment or setting in which people are enabled to perform to the best of their abilities. It is the main vehicle by which managers communicate what is required from employees and give feedback on how well they are achieving job goals.

Leadership Initiative: Leadership initiative is the ability to persuade others to seek defined objectives enthusiastically. Leadership is that ability to lead others, and it involves one person (the leader) trying to get others do something that he or she wants them to do. Leadership initiative is a display of ability to motivate and to integrate followers to achieve determined organizational goals.

Shared Responsibilities: Shared responsibility is the collaboration between two or more persons or bodies performing the same kind of activity in the creation of the content of an item. The contribution of each may form a separate and instinct part of the item, or the contribution of each may not be separable from that of the other(s).

\section{Concept of Employee Retention}

Employee retention is a systematic effort to create and foster an environment that encourages employees to remain employed by having policies and practices in place that address their diverse needs.

Employee-retention is generally 'the intention of employees to stay loyal to their current-workplace' (Huang et al., 2006). It is when employees are encouraged to remain in the organization for a long-period or until the ongoing-project is complete (Bidisha, 2013). Thus, as cited by Govaerts et al (2010), the survival of organizations was highly-dependent on their human-assets. Subsequently, has it created; a mandatory requirement for organizations to retain those human-assets (Horwitz et al.,2003).

Employee retention is concerned with keeping or encouraging employees to remain in an organization for a maximum period of time. Mita (2014) defined employee 
retention as "a technique adopted by businesses to maintain an effective workforce and at the same time meet operational requirements". According to Workforce Planning for Wisconsin State Government (2015), employee retention is "a systematic effort to create and foster an environment that encourages employees to remain employed by having policies and practices in place that address their diverse needs".

\section{Factor that Affect Employee Retention}

Thus, this literature review mainly focuses on recognizing the factors, and how they affect employee retention. Subsequently, as per studies of (George, 2015; Moncarz et al, 2009; Kossivi et al, 2016; Umamaheswari and Krishnan, 2013); compensation, work-life-balance, working-environment and superior-subordinate-relationship were noted as the commonly identified factors affecting employee-retention.

\section{Compensation}

Compensation was defined as the sum of both financial and non-financial remuneration, offered to employees by employers for the provision of their valuable services (Osibanjo et al.,2014). It constitutes of wages/salaries, bonuses, incentives and other fringe-benefits like holidays, health-insurance and company-vehicles (Patnaik and Padhi,2012).

On one hand, compensation was identified as a motivator; and therefore, a keyretention-strategy (Gardner et al.,2004), which had a direct relationship with employee retention (Hytter,2007).

\section{Work-Life-Balance}

According to Hudson (2005), work-life-balance was defined as a properly-planned balance between a person's personal-life and professional-life. Meanwhile, Estes and Michael (2005) stated that work-life-balance includes; flexible work-arrangements and leaves, including practices like; flextime, teleworking, job-sharing-schemes, family leave-programs and onsite child/elderly-care.

Over the years, work-life balance has become an increasingly significant factor for many professionals in organizations. Unlike in the past generations, in the present-day business environment, employees tend to demand for flexible work-schedules which brings a balance between their professional and personal lives (Ellenbecker,2004).

\section{Working-Environment}

A conducive working-environment refers to one with a pleasant-working-experience, adequate resources and a certain degree of flexibility, and is said to be contributing immensely in retaining employees (Alexander et al.,1998).

Furthermore, as per the researches of Miller et al (2001), it was identified that employees benefit from an environment that provides them a sense of belonging; and that will encourage them to stay committed and loyal to the workplace for longer (Irshad,2014). Meanwhile, according to Lok et al (2005), the presence of jobautonomy, positive feedback and innovative and supportive organization-culture too was noted to have a positive relationship with employee retention. 


\section{Superior-Subordinate Relationship}

Jasper (2007) identified superior-subordinate relationship as another major factor affecting employee retention. It was defined as the relationship between the supervisor and the employee. According to Pitts et al (1990), employee's perception about the organization was noted to be strongly influenced by their relationship with the supervisor. This will keep workers much engaged at work, with opencommunication with the supervisor and that will act as a pathway to gain employee commitment at work, thus raising retention levels (Landsman, 2008). If this relationship is not strong, employees will easily be demotivated and will seek other job opportunities elsewhere (Kooker et al., 2007) Employees who feel valued, recognized and honored with a sense of belongingness to the organization will be actively engaged in achieving the goals and objectives of the business, with increased productivity, while increasing retention rates (Mathis and Jackson, 2010). This will also build a high-level of trust between the employees and supervisors.

\section{Theoretical Literature}

\section{Realistic conflict theory (RCT)}

Managing workforce diversity is a concept that is well received by many organizations and appears very good in theory but has proved to be very complex in practical that many top managers are finding it very costly to implement. Many firms have invested heavily in workforce diversity management but have achieved little as far as the results are concerned (Daniel \& Bushardt, 2005). Diversity in business is beneficial to the performance of the business given the diverse abilities of the persons involved. Diversity is also difficult to handle as failure to manage diversity can affect the economical and social health of an organization. Diversity can be a breeding point for low morale, employee turnover, harassment, discrimination, absenteeism, and disruption to work teams that can results in a loss of productivity among the workforce (McArthur, 2010). When people feel isolated or discriminated against, their productivity is normally lowered.

Organizations have come up with ways of ensuring smooth running of business and good relations among their workforce by enhancing accountability for diversity at workplace. Code (2007) noted that a number of organizations are instituting diversity promoting behaviors and articulating model behaviors that give insight and guidance to workforces on how to carry out themselves. Some of these include team-building activities, rewarding employees for innovation and flexibility, encouraging employees to take ownership of ideas and follow through; recruiting, hiring and promoting a diverse workforce, providing performance feedback based on meeting objectives and behaviors, finding common ground and being a visible spokesperson for change (Code, 2007).

Workforce diversity encompasses different groups or categories of people who work together and there are several theories that try to explain the concept of intergroup relations that are relevant to organizations' workforce. These theories bring out the issues that are pertinent to workforce especially when they are categorized in to different groups brought by cultural and educational background, gender, disability and even intellectual disparity. This papers bases its arguments on two theories; the realistic conflict theory (RCT) which states that people's acts are driven by their self 
interests whereby conflicts can arise between different people of groups due to the drive of maximizing their own or groups interests at the expense of others (Sherif, 1966). When applied to workforce diversity, employees in different levels can act to protect their interests at workplace that can result to conflicts. Research done by Brock (2011) found out that the root cause of workplace dislike for others is competition over valued resources. People who belong to different groups view each other in negative terms and label each other as enemies. This can lead to unhealthy competition that comes in by discrimination and prejudice that arises.

\section{Social Identity Theory}

Another important theory that explains intergroup relations is social identity theory (Tajfel, 1982). This theory postulates that people tend to classify themselves in to social categories that have meaning for them and this shapes the way individuals interact with others from their own identity group and from other groups. Social identity stems from the knowledge of an individual that they belong to certain group. This categorization may result from the factors that are associated with a particular group formation making others fall in a particular group they would wish not to be associated with. At workplace, such categorization can lead to exclusion in which some individuals are left out of some activities by the virtue of belonging to a certain group. To support this, with the conflict theory, self-interest becomes the motivation for prohibiting certain individuals or groups from accessing valuable resources and power (Larkey, 1996). Those who belong to groups with higher perceived social status will accept and include people they consider to be like them, while excluding and discriminating against those they perceive to be different from them.

\section{Review of Related Literature}

Different researchers have conducted research to ascertain the effect of strategies for Managing Workforce Diversity on employee retention.

Kinyanjui, (2013) conducted a study to examine innovative Strategies for Managing Workforce Diversity in Kenyan Leading Corporations in Present Global Scenario. The area of the study was Kenya. The method of data analysis was simple percentage and descriptive frequent table this paper identifies innovative strategies for managing workforce diversity in Kenyan leading corporations in present global scenario. The paper looks at how communication strategies, performance management, leadership initiatives and shared responsibilities are used in managing workforce diversity. Activities of different corporations in Kenya are reviewed to identify those that are inclined to the management of workforce diversity.

Ugwuzor, (2014) conducted a study to examine the nature of the relationship between Workforce Diversity Management and Corporate Performance of manufacturing firms in Nigeria. Primary data was collected from Forty-two registered firms in South-South Nigeria using a five-point Likert-type scale questionnaire and personal interviews. The Spearman Rank Order Correlation Coefficient at 95\% confidence level and the Hierarchical Multiple Regression model were used to analyse the data. The findings revealed that the apparent low performance rate of the Study firms might be 
traceable to poor management of surface and deep level diversity. To optimize Corporate Performance therefore, it was recommended that managers should ensure that employees are "not at all" disturbed by issues bothering on diversity as raised in this Paper.

Oguegbulam, Onuoha \& Nwede (2017) conducted a study to examine the relationship between workforce diversity and employee retention in deposit money banks in Port Harcourt, Rivers State. A sample size of 167 was drawn from a population of 287. The statistical tool used in analyzing the null hypotheses was the Spearman's Rank order Correlation Coefficient. From the result of the analysis all the null hypotheses were rejected indicating that there is a significant relationship between workforce diversity and employee retention in deposit money banks in Port Harcourt, Rivers State. It was also deduced that organizational culture moderates the relationship between workforce diversity and employee retention in deposit money banks, in Port Harcourt Rivers State.

Akpakip, (2017) conducted a study to examine the effects of workforce diversity on employee performance in First Bank of Nigeria Plc, Ota, Ogun State. The survey research design method was adopted for the paper. The instrument used to gather relevant data for the study was the questionnaire. The study centred on the Nigerian Banking Sector to examine the level of diversity practiced in terms of gender, age, ethnicity and educational in Nigerian Organizations. First Bank of Nigeria Plc, Ota, Ogun State was the focal organization. A total of 81 copies of questionnaire were disseminated to the respondents of the study and they were all filled and returned and also relevant for the study. In order to attain the research objectives, four hypotheses were created. To test the hypotheses, Spearman Rank Correlation Coefficient Analysis was adopted, Regression Model, Anova were adopted to examine the relationship between variables and identify the influence of the independent variables on the dependent variable. The research findings showed all aspects of workforce diversity used in the study has a significant relationship with employee performance except for ethnic diversity. It was also discovered that gender, age and educational diversity have strong influence on employee performance.

Ogomegbunam \& Egbule (2015) conducted a study to assess the effects of workforce diversity on organizational effectiveness in Brewery industry using selected Breweries. Survey research design method was employed, stratified sampling method as well as simple random sampling was used. Linear regression and correlation analysis was employed for the analytical purpose to review the nature of statistical significance among variables. The findings show that there is a significant positive relationship between the variables of workforce diversity and organizational effectiveness; in particular cultural diversity was found to be more effective, also Team building and group training-which mediates between workforce diversity and organizational effectiveness. 


\section{Methodology}

The area of study was south-East of Nigeria Deposit Insurance Corporation. The choice of location is based on proximity. Again, another reason for chosen area of study is for effective coverage and cost minimization. Research design was sample survey research design. It details effective for studying the sample through the collation of relevant information from the participants. The population of this study comprises of the 120 staff of Nigeria Deposit Insurance Corporation. This study employs purposive and simple random sampling. In this type of sampling, the researcher includes in the sampling only those that posses some given characteristics and are ready and willing to be part of the study and they selected randomly. Information from questionnaires was analyzed using multi-norminal regression while method of data presentation was table. Statistical Package for Social Science (SPSS) is the computer Application Software that was used for the data analysis.

\section{Data Presentation and Analysis}

\section{Summary of Questionnaires Distributed}

One hundred and twenty (120) copies of questionnaires were designed and distributed to the respondents. Out of the 120 Questionnaires distributed, 96 or $80 \%$ percent were completed and returned while 24 or $20 \%$ percent were not returned. Therefore, 80 percent respondents were a good representation.

\section{Data Presentation}

In the first phase of the questionnaires, it provided the gender, age bracket, Marital status and Qualifications (see table ).

Table 1 Details of respondents by Gender

\begin{tabular}{|c|c|c|c|c|c|}
\hline \multicolumn{6}{|c|}{ Gender } \\
\hline & & $\begin{array}{c}\text { Frequenc } \\
y\end{array}$ & Percent & $\begin{array}{c}\text { Valid } \\
\text { Percent }\end{array}$ & $\begin{array}{c}\text { Cumulative } \\
\text { Percent }\end{array}$ \\
\hline \multirow{3}{*}{ Valid } & Male & 58 & 60.4 & 60.4 & 60.4 \\
\hline & Female & 38 & 39.6 & 39.6 & 100.0 \\
\hline & Total & 96 & 100.0 & 100.0 & \\
\hline
\end{tabular}

Sources: Field Survey August. 2018

This is frequent table of gender, it shows that 58 male respondents participated in the field survey given fifty (60) percent and 38 female respondents participated in the field survey given fifty (40\%) percent. 
Table 2 Details of respondents by Age Bracket

\begin{tabular}{|c|c|c|c|c|c|}
\hline \multicolumn{6}{|c|}{ Age } \\
\hline & & $\begin{array}{c}\text { Frequenc } \\
y\end{array}$ & Percent & $\begin{array}{c}\text { Valid } \\
\text { Percent }\end{array}$ & $\begin{array}{c}\text { Cumulative } \\
\text { Percent }\end{array}$ \\
\hline \multirow{5}{*}{ Valid } & 20-30yrs & 23 & 24.0 & 24.0 & 24.0 \\
\hline & 31-40yrs & 24 & 25.0 & 25.0 & 49.0 \\
\hline & 41-50yrs & 33 & 34.4 & 34.4 & 83.3 \\
\hline & 51-above & 16 & 16.7 & 16.7 & 100.0 \\
\hline & Total & 96 & 100.0 & 100.0 & \\
\hline
\end{tabular}

Sources: Field Survey August. 2018

The survey shows several Age brackets of the respondents, the respondents who are at the age bracket of 20-30 yrs were twenty three in number given twenty three percent (23\%), the respondents who are at the age bracket of 31-40 yrs were twenty four in number given twenty five percent (25\%), the respondents who are at the age bracket of 41-50 yrs were thirty three in number given thirty four percent (34\%), and finally the respondents who are at the age bracket of 51 and above were sixteen in number given seventeen percent (17\%).

Table 3 Details of respondents by Marital Status

Marital Status

\begin{tabular}{|l|r|r|r|r|}
\hline & $\begin{array}{c}\text { Frequenc } \\
\text { y }\end{array}$ & Percent & $\begin{array}{c}\text { Valid } \\
\text { Percent }\end{array}$ & $\begin{array}{c}\text { Cumulative } \\
\text { Percent }\end{array}$ \\
\hline Married & 45 & 46.9 & 46.9 & 46.9 \\
Single & 34 & 35.4 & 35.4 & 82.3 \\
Valid & 10 & 10.4 & 10.4 & 92.7 \\
Widow & 7 & 7.3 & 7.3 & 100.0 \\
Single Parents & 96 & 100.0 & 100.0 & \\
Total & & &
\end{tabular}

Sources: Field Survey August. 2018

The survey shows several marital status of the respondents, the married respondents were 45 in number given forty seven percent (47\%), the single respondents are thirty four in number given thirty five percent (35\%), the widow/widower respondents were ten in number given ten percent (10\%), while the single parents respondents were 7 in number given seven percent (7\%). 
Table 4 Details of Respondents by Academic Qualifications

\begin{tabular}{|l|r|r|r|r|}
\hline & $\begin{array}{c}\text { Qrequenc } \\
\text { y }\end{array}$ & Percent & $\begin{array}{c}\text { Valid } \\
\text { Percent }\end{array}$ & $\begin{array}{c}\text { Cumulative } \\
\text { Percent }\end{array}$ \\
\hline FSLC & 14 & 14.6 & 14.6 & 14.6 \\
WASC/SSCE & 15 & 15.6 & 15.6 & 30.2 \\
OND/NCE & 15 & 15.6 & 15.6 & 45.8 \\
Valid HND/B.sC & 48 & 50.0 & 50.0 & 95.8 \\
Post- & 4 & 4.2 & 4.2 & 100.0 \\
graduate & 96 & 100.0 & 100.0 & \\
Total & & & \\
\hline
\end{tabular}

Sources: Field Survey August. 2018

The survey shows several academic qualifications of the respondents, the holder of FSLC respondents were fourteen in number given fifteen percent (15\%), the holders of WASC/SSCE honour were fifteen in number given seventeen percent (17\%), the holders OND/NCE certificate were fifteen in number given seventeen percent (17\%), holders of $H N D / B . s C$ were forty eight in number given fifty percent (50\%), post-graduate certificate holders are 4 in number given four percent (4\%).

\section{Test of Hypotheses}

Null Hypothesis: workforce diversity strategies (performance Management, Leadership Initiative, Communication, Share Responsibility) have negative and insignificant effect on employee retention among staff of Nigeria Deposit Insurance Corporation.

Table 1 Summarized Regression Results for Hypotheses

Model Summary

\begin{tabular}{|l|c|r|r|r|}
\hline Model & R & R Square & $\begin{array}{c}\text { Adjusted R } \\
\text { Square }\end{array}$ & $\begin{array}{c}\text { Std. Error of } \\
\text { the Estimate }\end{array}$ \\
\hline 1 & $.699^{\mathrm{a}}$ & .488 & .464 & 1.16477 \\
\hline
\end{tabular}

a. Predictors: (Constant), performance Management, Leadership Initiative, Communication, Share Responsibility 
ANOVA $^{\mathrm{b}}$

\begin{tabular}{|c|c|c|c|c|c|c|}
\hline \multicolumn{2}{|c|}{ Model } & $\begin{array}{l}\text { Sum of } \\
\text { Squares }\end{array}$ & $\mathrm{df}$ & $\begin{array}{l}\text { Mean } \\
\text { Square }\end{array}$ & $F$ & Sig. \\
\hline \multirow[t]{3}{*}{1} & Regression & 111.171 & 4 & 27.793 & 20.486 & $.000^{a}$ \\
\hline & Residual & 116.675 & 86 & 1.357 & & \\
\hline & Total & 227.846 & 90 & & & \\
\hline
\end{tabular}

a. Predictors: (Constant), performance Management, Leadership Initiative, Communication, Share Responsibility

b. Dependent Variable: Employee Retention

\begin{tabular}{|ll|r|r|r|r|}
\hline \multirow{2}{*}{ Model } & \multicolumn{3}{|c|}{$\begin{array}{c}\text { Unstandardized } \\
\text { Coefficients }\end{array}$} & \multirow{2}{*}{} \\
\cline { 2 - 4 } & \multicolumn{1}{|c|}{$\mathrm{B}$} & Std. Error & \multicolumn{1}{c|}{$\mathrm{t}$} & \multicolumn{1}{c|}{ Sig. } \\
\hline $1 \quad$ (Constant) & 7.183 & .300 & 23.929 & .000 \\
& Communication & .304 & .101 & 3.009 & .001 \\
& Leadership Initiative & .122 & .013 & 9.384 & .000 \\
& Share Responsibility & .434 & .081 & 5.361 & .000 \\
& performance & .209 & .047 & 4.418 & .000 \\
Management & & & & \\
\hline
\end{tabular}

The result of the mulitiple-regression analysis summarized in table 5 shows the model for the effect of workforce diversity management strategies (performance Management, Leadership Initiative, Communication, Share Responsibility) on employee retention among staff of Nigeria Deposit Insurance Corporation.

Employee Retention $=\mathbf{7 . 1 8 3}+\mathbf{0 . 3 0 4}$ Communication $+\mathbf{0 . 1 2 2}$ leadership Initiative + 0.434 Share Responsibility + 0.209 Performance Management

The empirical result shows that the coefficient of performance Management, Leadership Initiative, Communication and Share Responsibilities have positive effect on employee retention; it means that workforce diversity management strategies have positive and direct effect on employee retention. The performance Management has twenty percent (20\%), Leadership Initiative has twelfth percent $(12 \%)$, Communication has thirty percent (30\%), Share Responsibility has forty three percent $(43 \%)$ direct effect on employee retention. The results of the $t-$ statistics denotes that the coefficient of workforce diversity management strategies were statistically significance. This is because observed values of their $t$ - statistics were greater than its P-values. The results of the $\mathrm{F}-$ statistical test shows that the overall regression of the hypothesis one was statistically significance. This is because observed values of the F-statistics (20.486) are great than its P-value (0.000). Again, our empirical result shows that the correlation value $(r)$ is 0.699. Explanatory power of the variables was fair and was positive. 


\section{Conclusion/Summary of Findings}

The study conducted that performance Management, Leadership Initiative, Communication and Share Responsibility are effective diversity management strategies to promote employee retention in Nigeria Deposit Insurance Corporation. The selected workforce diversity strategies have positive and significant effect on employee retention. The management that holds onto diversity management strategies will go a long way to control workforce diversity in the area such as gender, ethnicity, religion, age, functional background, and organizational tenure and differences with respect to attitudes, personality, and values of employee.

\section{Recommendations}

As a way of promoting employee retention and achieve organizational performance, the following recommendations have been suggested by this study.

1. Management of Nigeria Deposit Insurance Corporation should communication more and integrate employee on the need, mission, vision, of managerial decision and policies.

2. Management of Nigeria Deposit Insurance Corporation should adopt transformational leadership style to employee sense of belonging on the organization.

3. Management of Nigeria Deposit Insurance Corporation should employ managerial principle of share responsibility and performance management to achieve optimal organizational performance.

\section{References}

Seyed, A. M. (2004). Managing workforce diversity as an essential resource for improving organizational performance. International Journal of Productivity and Performance Management, 53(6), 521-531. http://dx.doi.org/10.1108/17410400410556183

Agricultural Development Corporation (ADC). (2007). Service Charter. Agricultural Development Corporation Nairobi, Kenya.

Agricultural Development Corporation [ADC]. (2011). FilmAid Program Assistant Job. Retrieved from http://kenyajobtube.blogspot.com/ 2011/ 11/ filmaidprogram-assistant-job-in-kakuma.html

Akpakip, C. E. (2017) Effect of Workforce Diversity on Employee Performance in Nigerian Banking Industry (A Study of First Bank Nigeria Ltd., Ota Branch) International Journal of Advanced Academic Research / Social \& Management Sciences / ISSN: 2488-9849 Vol. 3, Issue 8 (August 2017)

Alexander, J. A., Lichtenstein, R., O. H, H. J, Ullman, E. (1998) A causal model of voluntary turnover among nursing personnel in long-term psychiatric settings. Research in Nursing and Health. 21(1). p.415-427.

Bidisha, L. D., Mukulesh, B. (2013) Employee retention: A review of literature. Journal of Business and Management. 14(1). p.8-16.

Lawanna, B. (2011). What is Workplace Aggression? Retrieved from http://www.articlesbase.com/career-management-articles/what-isworkplace- aggression-5043076.html 
Chepng'eno, L. S. (2012). The effects of work life balance initiatives on the performance of the staff at agricultural development corporation of Kenya center. Kenyatta University

Code, M. F. (2007). Enhancing Workplace Diversity - Strategies for Success. Ogletree, Deakins, Greenville. Cox, T. (2001). Creating the Multicultural Organization. San Francisco: Jossey-Bass, 2001.

Crowe, M. (1997). Open Communication Key to Success of Diverse Workplace. Silicon Valley/San Jose Business Journal.

Daniel, F., \& Bushardt, S. C. (2005). Managing Diversity from a Strategic Perspective: A Competing Values Approach.

Dass, P., \& Parker, B. (1999). Strategies for Managing Human Resource Diversity: From Resistance to Learning. The Academy of Management Executive (1993-2005), 13(2), 68-80.

Vaus, D. A. (2003). Research Design in Social Research. London: Sage Publications Ltd.

Edeltraud, H., \& Ukur, G. (2011). Challenging Diversity Management On the meaning of cultural context: the Case of Kenya.

Ellenbecker, C. H. (2004) A theoretical model of Job Retention for Home Health Care Nurses. Journal of Advanced Nursing. 47(1). p.303-310.

George, C. (2015) Retaining professional workers: what makes them stay? Employee Relations. [Online] Emerald 37(1). P.102.

Gottfredson, L. S. (1992). Dilemmas in developing diversity programs. In S. E. Jackson \& Associates (Eds.), Diversity in the Workplace. New York: Guilford Press.

Govaerts, et al. (2015) Influence of learning and working climate on the retention of talented employees. Journal of Workplace Learning. [Online] Emerald Insight 23(1). Pg. 37-38.

Hawthorne, M. (2012). Management Theories \& Concepts at the Workplace. Retrieved from

http://smallbusiness.chron.com/management-theories-concepts-workplace17693.html

Holt, M. (2010). Challenges of Diversity Management. Retrieved from http://smallbusiness.chron.com/challenges-diversity-management-3044.html

Horwitz, F. M., Heng, C.T. and Quazi, H.A. (2003) Finders, keepers? Attracting, motivating and retaining knowledge workers. Human Resource Management journal. 13(4) .p. 23-44.

Huang, I. C., Lin, H. V., Chuang, C. H. (2006) Constructing factors related to worker retention. International Journal of Manpower. 27(5). p.491-508.

Human, L. (1996). Managing workforce diversity: a critique and example from South Africa. International Journal of Manpower, 17(4/5), 46-64. http://dx.doi.org/10.1108/01437729610127659

Irshad, M. (2014) Factors affecting employee retention: evidence from literature review. Abasyn Journal of Social Sciences. EBSCOhost. 4(1). p.84-97.

Jasper, M. (2007) The significance of the working environment to nurses' job satisfaction and retention. Journal of nursing management. 15(3) .p. 245-247

Kanyinga, K., \& Mitullah, W. (2006). The Non-Profit Sector In Kenya: What we know and what we don't know Popular Version. Institute for Development Studies, University of Nairobi. 
Kinyanjui, S. (2013) Innovative Strategies for Managing Workforce Diversity in Kenyan Leading Corporations in Present Global Scenario International Journal of Business and Management; Vol. 8, No. 15; 2013

Kooker, B. M., Shoultz, J., Codier, E. E. (2007) Identifying Emotional Intelligence in Professional Nursing Practice. Journal of Professional Nursing. 23(1). p.30-36.

Kumar, J. (2012) Hrm Practice on the Retention of Employees of the Information Technology Sector. International Journal of Scientific Research. [Online] 1(4). Pg. 108-110. HF16A1IBM - CB006122

Landsman, M. J., (2008) Pathways to organization commitment. Administration in social work. 32(2). p.105-132.

Larkey, L. K. (1996). Toward a theory of communicative interactions in culturally diverse workgroups. Academy of Management Review, 21(2), 463-491.

Lauring, J. (2007). Obstacles to Innovative Interaction: Communication Management in Culturally Diverse Organizations. Journal of Intercultural Communication, 15.

Marquis, J. P., Lim, N., Scott, L. M., Harrell, M. C., \& Kavanagh, J. (2008). Managing Diversity in Corporate America An Exploratory Analysis.

Mary, K. J. (2002). Managing Diversity in the public service: One of the least tackled issues. Lessons learnt from South Africa. Paper presented at the 63rd International Conference of the American society for Public Administration in Phoenix Arizona.

Mathis, R., Jackson, J. (2010) Human Resource Management. 13th Edition. USA: SouthWestern Cengage-learning.

Mathooko, P., Sitati, N., \& Lillian, G. O. (2011). The Effects of Performance Appraisal System on Civil Servants Job Perfomance and Motivation in Kenya: A Case Study Of Ministry of State For Public Service. Kabarak University First International Conference.

Mayhew, R. (2010). Communication \& Diversity in the Workplace. Retrieved from http://smallbusiness.chron.com/communication-diversity-workplace1389.html

McArthur, E. K. (2010). Managing Diversity for Success Workforce Diversity Network. Retrieved from

http://www.workforcediversitynetwork.com/res_articles_managingdiversity_ mcarthur aspx

Miring'u, A. (2011). An Analysis of the Effect of Corporate Governance on Performance of Commercial State Corporations in Kenya. International Journal of Business and Public Management, 1(1).

Moncarz, E. Zhao, J., Kay, C. (2009). An exploratory study of US lodging properties' organizational practices on employee turnover and retention. International Journal of Contemporary Hospitality Management. 21. p.437- 458.

National Integration Working Group for Workplaces [NIWGW]. (2011). Managing Workplace Diversity: A toolkit for organizations. Office of State Personnel [OSP]. (2008). Diversity management initiatives. Retrieved from http://www.performancesolutions.nc.gov/developmentinitiatives/DiversityM anagement/DiversityManagem entInitiatives/index.asp 
Ogomegbunam, A. O \& Egbule, S. (2015) Workforce Diversity and Organizational Effectiveness in Nigerian Brewery Industry. Developing Country Studies www.iiste.org Vol.5, No.8, 2015

Oguegbulam, R. O., Onuoha, B. C \& Nwede, I (2017) Workforce Diversity And Employee Retention In Deposit Money Banks Port Harcourt, Rivers State. International Journal of Advanced Academic Research / Social \& Management Sciences / ISSN: 2488-9849 Vol. 3, Issue 8 (August 2017)

Olsen, J. E., \& Martins, L. L. (2012). Understanding organizational diversity management programs: A theoretical framework and directions for future research. Journal of Organizational Behavior, 33(8), 1168-1187

Osibanjo, O. A., Adeniji, A. A., Falola, H. O., Heirsmac, P. T. (2014) Compensation package: a strategic tool for employees' performance and retention. Leonardo Journal of Sciences. (25). p.65-84.

Otike, F. W., Messah, O. B., \& Mwalekwa, K. F. (2009). Effects of Workplace Diversity Management on Organizational Effectiveness: a case study. European Journal of Business and Management.

Patnaik, B. C. M., Padhi, P. C. (2012) Compensation management: a theoretical preview. Trans Asian Journal of Marketing and Management Research. 1(1). p.39-45.

Pitts, D., Marvel, J., Fernandez, S. (2011) So hard to say Goodbye? Turnover intention among US Federal Employees. Public administration Review. 71(1). p.751-760.

Rachele J. S. (2010). Equality, Diversity \& Human Rights: Driving culture change through innovative governance. Kingstone Business School UK, summer conference paper Sorenze, France.

Ribbink, K. (2003). Seven Ways to Better Communicate in Today's Diverse WorkplaceSeven Tips for Communicating In Today's Diverse Workplace. Harvard Business School, February, 2003.

Roberts, K., Kossek, E. E., \& Ozeki, C. (1998). Managing the Global Workforce: Challenges and Strategies.

Rosen, B., \& Lovelace, K. (1994). Fitting square pegs into round holes-diversity management programs. Retrieved from http://findarticles.com/p/articles/mi_ m3495/is_n1_v39/ai_15162180/

Safaricom. (2012). Job Profile for General Manager. Safaricom Investment CoOperative. Retrieved from http://sic.co.ke/downloads/6b723_VACANCYGENERALMANAGER-JD.pdf

Sekun, N. (2004). Human Resource Management of Price Waterhouse Coopers, with special reference to Cambodia. ASEAN Business Case Studies No 23.

Sherif, M. (1966). Group conflict and co-operation: Their social psychology. London:

Routledge., Paul, K. Smit, P. J., Brevis, T., Cronje, G. J. De J., \& Vrba, M. J. (2008). Management Principles: A Contemporary Edition for Africa (5th ed.).

Tajfel, H. (1982). Social identity and intergroup relations. Cambridge, UK: Cambridge University Press. The Academy of Management Executive (1993-2005), 12(4).

Ugwuzor, M. (2014) Workforce Diversity Management and Corporate Performance of Firms in Nigeria International Journal of Business and Management Review Vol.2, No.4, pp.36-46,September 2014. 
Umamaheswari, S., Krishnan, J. (2016) Work Force Retention: Role of work environment, organization commitment, supervisor support, and training and development in ceramic sanitary ware house industries in India. Journal of Industrial Engineering and Management.

US Nuclear Regulatory Commission [US NRC]. (2004). Comprehensive Diversity Management Plan. Washington, DC.

Waiganjo, E. W., Mukulu, E., \& Kahiri, J. (2012). Relationship between Strategic Human Resource Management and Firm Performance of Kenya's Corporate Organizations 2012. International Journal of Humanities and Social Science, 2(10).

Wentling, R. M. (2000). Evaluation of diversity initiatives in multinational corporations. Human Resource Development International. http://dx.doi.org/10.1080/713767865

Wentling, R. M., \& Palma-Rivas, N. (1998). Status and future trends of diversity initiatives in the workplace: Diversity experts' perspective. Human Resource Development Quarterly, 9(3), 235-253.

Wentling, R. M., \& Palma-Rivas, N. (2000). Current Status of Diversity Initiatives in Selected Multinational Corporations. Human Resource Development Quarterly, 11(1). 